\title{
BMJ Global Health Do current guidelines for waist circumference apply to black Africans? Prediction of insulin resistance by waist circumference among Africans living in America
}

\author{
J Damascene Kabakambira, ${ }^{1,2}$ Rafeal L Baker Jr, ${ }^{1}$ Sara M Briker, ${ }^{1}$ \\ Amber B Courville, ${ }^{3}$ Lilian S Mabundo, ${ }^{1}$ Christopher W DuBose, ${ }^{1}$ \\ Stephanie T Chung, ${ }^{1}$ Robert H Eckel, ${ }^{4}$ Anne E Sumner ${ }^{1,2}$
}

To cite: Kabakambira JD, Baker Jr RL, Briker SM, et al. Do current guidelines for waist circumference apply to black Africans? Prediction of insulin resistance by waist circumference among Africans living in America. BMJ Glob Health 2018;3:e001057. doi:10.1136/ bmjgh-2018-001057

Handling editor Seye Abimbola

- Additional material is published online only. To view please visit the journal online (http://dx.doi.org/10.1136/ bmjgh-2018-001057).

JDK and RLB contributed equally.

JDK and RLB are joint first authors.

Received 11 July 2018 Revised 19 August 2018 Accepted 20 August 2018

Check for updates

(c) Author(s) (or their employer(s)) 2018. Re-use permitted under CC BY-NC. No commercial re-use. See rights and permissions. Published by BMJ.

For numbered affiliations see end of article.

Correspondence to Dr Anne E Sumner; annes@intra.niddk.nih.gov

\section{ABSTRACT}

Background To lower the risk of diabetes and heart disease in Africa, identification of African-centred thresholds for inexpensive biomarkers of insulin resistance (IR) is essential. The waist circumference (WC) thresholds that predicts IR in African men and women have not been established, but investigations recently conducted in Africa using indirect measures of IR suggest IR is predicted by WC of 80-95 cm in men and $90-99 \mathrm{~cm}$ in women. These WC cannot be used for guidelines until validated by direct measurements of IR and visceral adipose tissue (VAT). Therefore, we determined in a group of African-born black people living in America (A) the WC, which predicts IR and (B) the influence of abdominal fat distribution on IR. Methods The 375 participants (age $38 \pm 10$ years (mean \pm SD), 67\% men) had IR determined by HOMAIR and Matsuda index. VAT and subcutaneous adipose tissue (SAT) were measured by abdominal CT scans. Optimal WC for the prediction of IR was determined in sex-specific analyses by area under the receiver operating characteristic (AUC-ROC) and Youden index. Results Women had more SAT $(203 \pm 114$ vs $\left.128 \pm 74 \mathrm{~cm}^{2}\right)$ and less VAT than men $(63 \pm 48 \mathrm{vs}$ $\left.117 \pm 72 \mathrm{~cm}^{2}, p<0.001\right)$. Optimal WC for prediction of IR in men and women were: $91 \mathrm{~cm}$ (AUC-ROC: $0.80 \pm 0.03($ mean \pm SE)) and $96 \mathrm{~cm}$ (AUC-ROC: $0.81 \pm 0.08)$, respectively. Regression analyses revealed a significant sex-VAT interaction $(p<0.001)$. Therefore, for every unit increase in VAT, women had a 0.94 higher unit increase in SAT and 0.07 higher unit increase in WC than men.

Conclusion Working with a group of Africanborn black people living in America, we accessed technology, which validated observations made in Africa. Higher SAT at every level of VAT explained why the WC that predicted IR was higher in women $(96 \mathrm{~cm})$ than men $(91 \mathrm{~cm})$. For Africans to benefit from WC measurements, convening a panel of experts to develop evidence-based African-centred WC guidelines may be the way forward.

\section{Key questions}

What is already known?

- Waist circumference is an inexpensive biomarker for insulin resistance, a proxy for visceral adipose tissue and a better predictor than body mass index for risk for diabetes and cardiovascular disease.

- As the waist circumference that predicts insulin resistance in Africans is unknown, both the International Diabetes Federation and the American Heart Association recommend using waist circumference thresholds determined in whites

What are the new findings?

- Working with a group of African-born black people living in America, the waist circumference that predicted insulin resistance in men and women were 91 $\mathrm{cm}$ and $96 \mathrm{~cm}$, respectively.

- The waist circumference that predicted insulin resistance was higher in women than men because at every level of visceral adipose tissue, women had more subcutaneous adipose tissue.

\section{What do the new findings imply?}

- As waist circumference thresholds determined in Africans differ from waist circumference used in whites, convening an expert panel to establish evidence-based African-specific guidelines will make it possible for Africans to benefit from this low cost, valuable marker of insulin resistance.

\section{INTRODUCTION}

Non-communicable diseases such as diabetes and cardiovascular disease are common in Africa. ${ }^{12}$ Both diseases are closely linked to insulin resistance (IR) ${ }^{3-5}$ Eliminating global health inequities related to IR requires the development of population-specific screening tests. Waist circumference (WC) as a proxy for visceral adipose tissue (VAT) 
is an inexpensive marker of IR. ${ }^{3}{ }^{6}$ The link between IR and VAT is universally accepted even though the mechanisms by which VAT promotes IR are not understood. ${ }^{3}$ 7-11 Overall, major differences exist by sex and race/ethnicity in the relationship between IR, VAT and WC. ${ }^{34612}$

In 2008, the WHO convened a committee to establish international guidelines for WC thresholds. ${ }^{6}$ Due to the paucity of data in Africans, WHO decided against providing WC for guidelines for Africans. The International Diabetes Federation and the American Heart Association/National Heart Lung and Blood Institute (AHA/NHLBI) took a different approach. ${ }^{34}$ The International Diabetes Federation decided that until African data were available, WC thresholds established in Europeans should be applied to Africans (men: $94 \mathrm{~cm}$; women: $80 \mathrm{~cm}$ ). AHA/NHLBI decided to apply the WC used in America to Africans (men: $102 \mathrm{~cm}$; women: 88 $\mathrm{cm}) .^{34}$

Since 2011, eight investigations designed to identify the WC that predicts IR have been conducted in South Africa, the Democratic Republic of Congo and Benin ${ }^{13-20}$ (table 1). These studies relied on the five parameters of the metabolic syndrome. The components of the metabolic syndrome are: triglyceride, high-density lipoprotein-cholesterol, fasting glucose, blood pressure and WC. ${ }^{3}$ The WC thresholds reported in these eight studies were the WC optimally predicted by one, two or three metabolic syndrome components.

The results of these eight studies differ from International Diabetes Federation and AHA/NHLBI guidelines in three ways (table 1) ${ }^{13-20}$ First, the authors report that the WC of risk is higher in women than men. ${ }^{13} 15-20$ Second, they report that the WC of risk in women is 90-99 $\mathrm{cm}$. These WC are higher than the thresholds recommended for women by both the International Diabetes Federation and AHA/NHLBI $(80 \mathrm{~cm}$ and $88 \mathrm{~cm}$, respectively). Third, they state that the WC of risk in African men is 80-95 cm and therefore lower than guidelines for AHA/NHLBI but not International Diabetes Federation.

Data from these eight studies are important but not sufficient for establishing guidelines. ${ }^{13-20}$ These studies leveraged the readily available data points of the metabolic syndrome. However, metabolic syndrome variables were chosen because of their individual association with IR and not their ability to predict each other. ${ }^{3}$ To establish the WC that predicts IR in Africans, IR must be measured, VAT quantified and the relationship between IR, WC and VAT determined.

Resources to collect these data are not readily available in Africa. However, IR measurements and CT scanners programmed to assess abdominal fat distribution are available in America. Therefore, our goals were to determine in a group of African-born black people living in America (A) the WC that best predicts IR and (B) how sex differences in abdominal fat distribution affect the WC that predicts IR.
METHODS

\section{Population}

The Africans in America cohort was established to evaluate the cardiometabolic health of Africans living in the USA. $^{21-24}$

Recruitment occurred between February 2008 and January 2018 and was achieved by newspaper advertisements $(43 \%)$, previous participant referrals $(30 \%)$ and flyers $(6 \%)$. The remaining $21 \%$ of participants heard about the study at community events, church meetings and the National Institutes of Health (NIH) website. The National Institute of Diabetes Digestive and Kidney Diseases Institutional Review Board (ClinicalTrials.gov identifier: NCT00001853) approved the study. Informed written consent was obtained prior to enrolment.

During pre-enrolment telephone interviews, callers had to report that they were born in sub-Saharan Africa to two black parents who were also born in sub-Saharan Africa. In addition, they had to state they were healthy and to their knowledge did not have diabetes.

Four hundred and nine African-born black people living in America participated in visit 1 (figure 1). Thirty Africans did not proceed to visit 2 because of anaemia $(n=8)$, pregnancy $(n=3)$, increased liver function tests (LFT) $(n=1)$ or scheduling conflicts with work $(n=18)$. Of the 379 enrollees who did go on to visit 2, two did not have WC measured, one had extreme IR (fasting insulin was $803.6 \mathrm{pmol} / \mathrm{L}$ ) and one had haemolysed blood samples at baseline so IR could not be calculated by either HOMA-IR or Matsuda index. Therefore, 375 Africans (67\% male, age $38 \pm 10$ (mean \pm SD), range 20-64 years) were evaluated. The African regions of origin of the participants were: West (52\%), Central (23\%) and East $(25 \%)$.

All participants had two outpatient visits at the NIH Clinical Center, Bethesda, Maryland. Sixty-six consecutively enrolled participants had three visits.

At visit 1, a history, physical and EKG were performed. The history includes information on alcohol intake. Routine blood tests were performed to confirm the absence of anaemia, kidney, liver and thyroid disease.

For visit 2, participants fasted for 12 hours and came to the Clinical Center at 07:00. Weight was measured using a calibrated digital scale (Scale-Tronix 5702, Carol Stream, Illinois, USA). Height was measured in triplicate with a wall stadiometer (Seca 242, Hanover, Maryland, USA). Then the participant rested quietly in a chair for $20 \mathrm{~min}$. $\mathrm{BP}$ was taken three times, 2 min apart with an automated cuff (Critikon BP Cuff, General Electric) and machine (Philips SureSigns vs3). The mean of the last two readings was recorded.

Glucose tolerance was determined by an OGTT (Trutol 75; Custom Laboratories, Baltimore, Maryland, USA) with samples for glucose and insulin taken at $-15,0,30,60$ and 120 min.

Glucose tolerance status was diagnosed according to glucose concentrations for the OGTT. ${ }^{25}$ Individuals identified with either prediabetes or diabetes were combined into a single group and referred to as abnormal glucose 
Table 1 Literature review of WC in Africans that predicts insulin resistance or metabolic syndrome

\begin{tabular}{|c|c|c|c|c|c|c|}
\hline Article & Country & Number & $\begin{array}{l}\text { Technique to } \\
\text { determine } \\
\text { IR }\end{array}$ & $\begin{array}{l}\text { Statistic for } \\
\text { optimal WC* }\end{array}$ & $\begin{array}{l}\text { Optimal WC } \\
\text { men }\end{array}$ & $\begin{array}{l}\text { Optimal WC } \\
\text { women }\end{array}$ \\
\hline Motala et $a l^{18} 2011$ & South Africa & $\begin{array}{l}\text { Men: } n=189 \\
\text { women } n=758\end{array}$ & $\begin{array}{l}\text { Two or more } \\
\text { metabolic } \\
\text { syndrome } \\
\text { variables. }\end{array}$ & $\begin{array}{l}\text { AUC-ROC } \\
\text { Youden } \\
\text { index }\end{array}$ & $86 \mathrm{~cm}$ & $92 \mathrm{~cm}$ \\
\hline $\begin{array}{l}\text { Prinsloo et }\left.a\right|^{20} \\
2011\end{array}$ & $\begin{array}{l}\text { South } \\
\text { Africa }\end{array}$ & $\begin{array}{l}\text { Men: } n=80 \\
\text { women: } n=93 \text {. }\end{array}$ & $\begin{array}{l}\text { One or more } \\
\text { metabolic } \\
\text { syndrome } \\
\text { variable. }\end{array}$ & $\begin{array}{l}\text { AUC-ROC } \\
\text { Youden } \\
\text { index }\end{array}$ & $90 \mathrm{~cm}$ & $98 \mathrm{~cm}$ \\
\hline $\begin{array}{l}\text { Crowther et } \text { al }^{14} \\
2012\end{array}$ & South Africa & $\begin{array}{l}\text { Women: } \\
n=1251\end{array}$ & $\begin{array}{l}\text { (A)Three or } \\
\text { more metabolic } \\
\text { syndrome } \\
\text { variables and (B) } \\
\text { HOMA-IR (top } \\
\text { quartile). }\end{array}$ & $\begin{array}{l}\text { AUC-ROC } \\
\text { Youden } \\
\text { index }\end{array}$ & $\mathrm{N} / \mathrm{A}$ & $\begin{array}{l}\text { (A) } 92 \mathrm{~cm} \text {; (B) } 89 \\
\mathrm{~cm} .\end{array}$ \\
\hline $\begin{array}{l}\text { Katchunga et } a l^{17} \\
2013\end{array}$ & $\begin{array}{l}\text { Democratic } \\
\text { Republic of } \\
\text { Congo }\end{array}$ & $\begin{array}{l}\text { Men: } n=143 ; \\
\text { women: } n=217 \text {. }\end{array}$ & $\begin{array}{l}\text { Two or more } \\
\text { metabolic } \\
\text { syndrome } \\
\text { variables plus } \\
\text { excess VAT } \\
\text { by bioelectric } \\
\text { impedance. }\end{array}$ & $\begin{array}{l}\text { AUC-ROC } \\
\text { Youden } \\
\text { index }\end{array}$ & $95 \mathrm{~cm}$ & $99 \mathrm{~cm}$ \\
\hline Hoebel et al ${ }^{16} 2014$ & South Africa & $\begin{array}{l}\text { Men: } n=74 ; \\
\text { women: } n=76 \text {. }\end{array}$ & $\begin{array}{l}\text { Two or more } \\
\text { metabolic } \\
\text { syndrome } \\
\text { variables. }\end{array}$ & $\begin{array}{l}\text { AUC-ROC } \\
\text { Youden } \\
\text { index }\end{array}$ & $92 \mathrm{~cm}$ & $94 \mathrm{~cm}$ \\
\hline $\begin{array}{l}\text { El Mabchour et al }{ }^{15} \\
2015\end{array}$ & Benin \& Haiti & $\begin{array}{l}\text { Men: } n=235 \\
\text { women: } n=217 \text {. }\end{array}$ & $\begin{array}{l}\text { Two or more } \\
\text { cardiac risk } \\
\text { factors such } \\
\text { as metabolic } \\
\text { syndrome, } \\
\text { HOMA-IR } \\
\text { (top quartile), } \\
\text { ThsCRP, } \uparrow \text { Chol/ } \\
\text { HDL ratio. }\end{array}$ & $\begin{array}{l}\text { AUC-ROC } \\
\text { Youden } \\
\text { index }\end{array}$ & $80 \mathrm{~cm}$ & $94 \mathrm{~cm}$ \\
\hline $\begin{array}{l}\text { Agueh et } a l^{13} \\
2015\end{array}$ & Benin & $\begin{array}{l}\text { Men: } n=208 ; \\
\text { women: } n=208 \text {. }\end{array}$ & $\begin{array}{l}\text { One or more } \\
\text { metabolic } \\
\text { syndrome } \\
\text { variables. }\end{array}$ & $\begin{array}{l}\text { AUC-ROC } \\
\text { Youden } \\
\text { index }\end{array}$ & $80 \mathrm{~cm}$ & $90 \mathrm{~cm}$ \\
\hline $\begin{array}{l}\text { Peer et al }{ }^{19} \\
2016\end{array}$ & $\begin{array}{l}\text { South } \\
\text { Africa }\end{array}$ & $\begin{array}{l}\text { Men: } n=392 ; \\
\text { women: } n=707 \text {. }\end{array}$ & $\begin{array}{l}\text { Two or more } \\
\text { metabolic } \\
\text { syndrome } \\
\text { variables. }\end{array}$ & $\begin{array}{l}\text { AUC-ROC } \\
\text { Youden } \\
\text { index }\end{array}$ & $84 \mathrm{~cm}$ & $94 \mathrm{~cm}$ \\
\hline
\end{tabular}

*Statistic for calculation of the optimal waist circumference (WC) for the prediction of insulin resistance (IR) was the Youden index calculated on the basis of the area under the receiver operatoring characteristic curve (AUC-ROC).

$\mathrm{HDL}$, high density lipoprotein-cholesterol.

tolerant (Abnl-GT). After the OGTT was completed, an CT scan (Siemens and Somatom Force Scanner, Munich, Germany) was performed at the level of the L2-3 vertebrae using automated software for the measurement of VAT and subcutaneous adipose tissue (SAT) (figure 2). ${ }^{26}$

At visit 3, 66 consecutively enrolled participants $(60 \%$ male) had an insulin modified-frequently sampled intravenous glucose tolerance test performed. An intravenous catheter was placed in each antecubital vein. Baseline samples were obtained. Dextrose $(0.3 \mathrm{~g} / \mathrm{kg})$ was administered intravenously over $1 \mathrm{~min}$. Insulin $(0.03 \mathrm{U} / \mathrm{kg})$ was given as a bolus at $20 \mathrm{~min}$. Samples for glucose and insulin were drawn at: $-10,-1,0,1,2,3,4,5,6,7,8,10$, $12,14,16,19,22,23,24,25,27,30,40,50,60,70,80,90$, $100,120,150$ and $180 \mathrm{~min}$. Glucose and insulin concentrations were entered into the minimal model for calculation of the insulin sensitivity index (MinMOD Millenium V.6.02) ${ }^{27}$ 


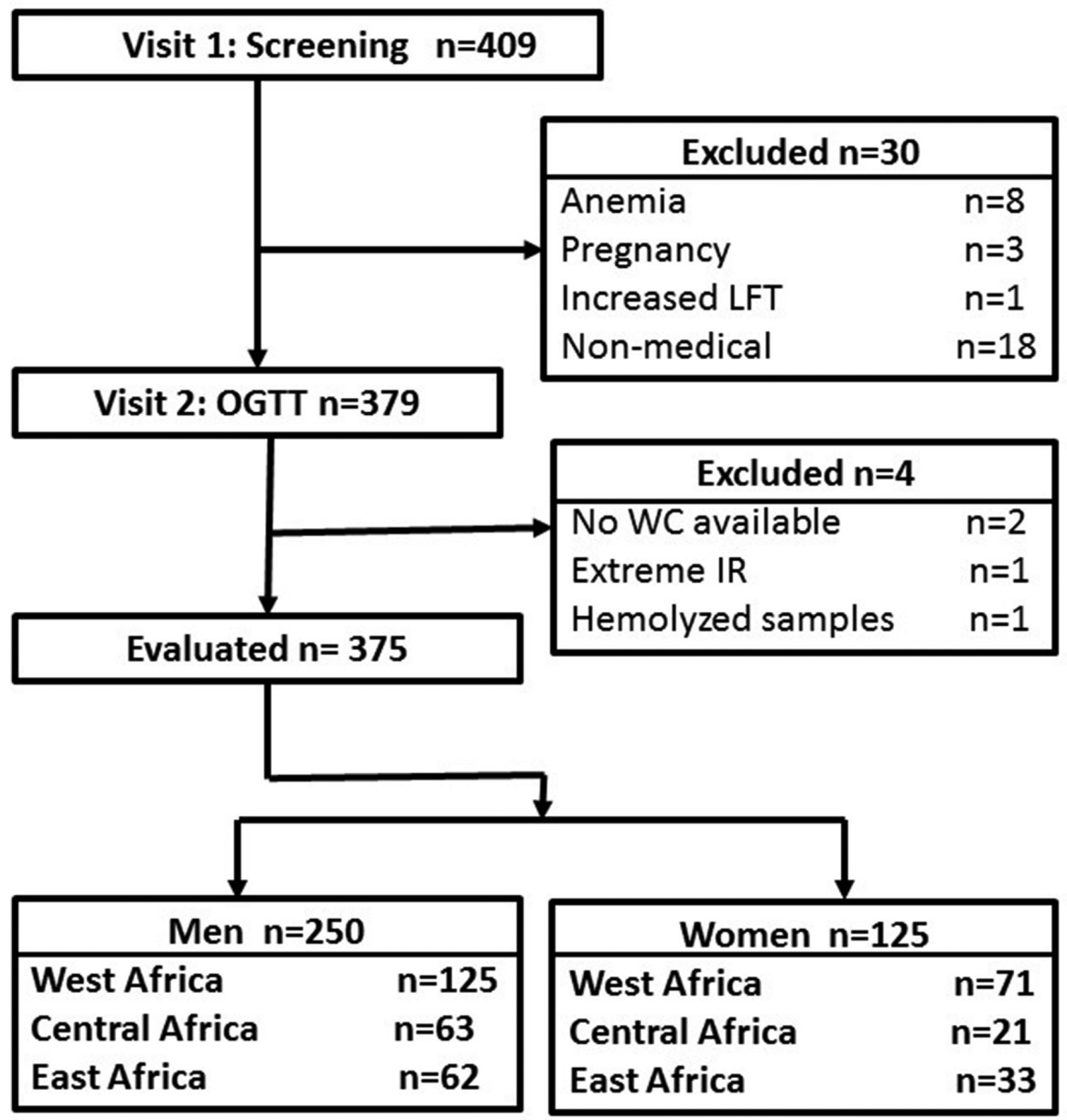

Figure 1 Flow diagram for enrolment. OGTT, oral glucose tolerance test; WC, waist circumference.

\section{Waist circumferences}

Immediately prior to the OGTT while the participant was still fasting, WC was measured at two levels: (1) at the superior border of the iliac crest according to National Health and Nutrition Examination Survey protocol and referred to as WC1 and (2) at the midpoint between the iliac crest and the lowest palpable rib according to WHO protocol and referred to as WC2 $\left({ }^{628}\right)$. Measurements were taken in triplicate at the end of expiration using a stretch-resistant tape measure with the person standing with feet hip width apart and weight evenly distributed. The mean of three values was recorded.

\section{Insulin resistance}

IR was measured in three ways:

Method 1: HOMA-IR:

$\left(\frac{\text { fasting glucose }\left(\frac{m m o l}{L}\right) \times \text { fasting insulin }(\mu U / m L)}{22.5}\right)$ using the threshold at the highest quartile of the population distribution.

Method 2: Matsuda Index: 10,000

$\left(\frac{1 \text { fasting glucose } \times \text { fasting insulin } \times \text { mean glucose } \times \text { mean insulin }}{\sqrt{2}}\right)$ using the threshold at the lowest quartile of the population distribution.
Method 3

Insulin sensitivity index:

Calculated from the minimal model using MinMOD Millenium V.6.02. based on the glucose and insulin concentrations obtained during the insulin modified-frequently sampled intravenous glucose tolerance test performed at visit $3 .^{27}$

\section{Insulin secretion}

The insulinogenic index:

$$
\left(\frac{30 \mathrm{~min} \text { insulin-fasting insulin }}{30 \mathrm{~min} \text { glucose-fasting glucose }}\right) \text {. }
$$

\section{Glucose tolerance status group}

The cohort was divided into four groups according to the glucose tolerance status determined at visit 2 by the OGTT:

Group 1: normal glucose tolerant (NGT) (reference). Group 2: NGT and IR.

Group 3: Abnl-GT and IR.

Group 4: Abnl-GT and not IR.

\section{Assays}

Glucose was measured in plasma and insulin was measured in serum (Roche Cobas 6000 analyzer, Roche Diagnostics). 


\section{African Man (Uganda)}

Age 54, BMI 36.1

WC $126 \mathrm{~cm}$

VAT $390 \mathrm{~cm}^{2}$

SAT $315 \mathrm{~cm}^{2}$

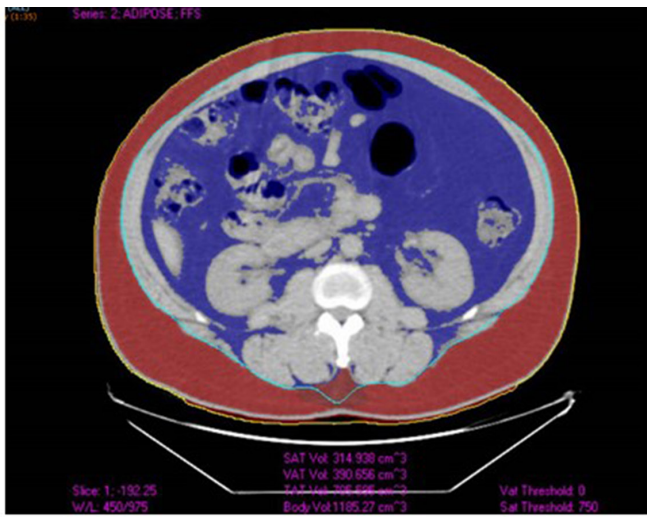

African Woman (Ghana)

Age 54, BMI 34.7

WC $124 \mathrm{~cm}$

VAT $100 \mathrm{~cm}^{2}$

SAT $448 \mathrm{~cm}^{2}$

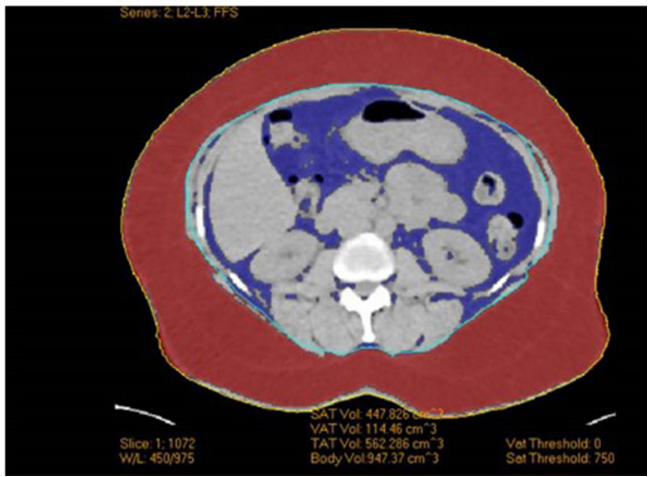

Figure 2 Example of automated VAT and SAT scans in African immigrant man and woman of similar age, BMI and WC. BMI, body mass index; SAT, subcutaneous adipose tissue; VAT, visceral adipose tissue; WC, waist circumference.

\section{Statistical analyses}

Data are presented as mean $\pm \mathrm{SD}$. Comparisons of Africans born in West, Central and East Africa were by one-way analysis of variance with Bonferroni corrections for continuous variables and $\chi^{2}$ test for categorical variables. With the NGT group (group 1) as the reference group, multiple regression analyses were used to compare characteristics of groups 2, 3 and 4 to group 1.

All analyses for the determination of the WC that predicts IR were performed separately for men and women. Area under the receiver operating characteristic (AUC-ROC) curves were calculated to determine the ability of WC to predict IR. In addition, the optimal WC threshold for the prediction of IR was determined by the Youden index. The Youden index represents the maximum value of $1-$ (sensitivity+specificity) and is considered to be optimal combination of sensitivity and specificity. Pearson correlations were used to determine relationships between WC and VAT, and SAT and VAT. In multiple regression analyses with WC as the dependent variable, the interaction between sex and VAT and the effect of length of stay in the USA were evaluated.

Study data were collected and managed using Research Electronic Data Capture, an electronic data capture tool hosted by National Instutite of Diabetes Digestive and Kidney Diseases (NIDDK). ${ }^{29} \mathrm{P}$ values $<0.05$ were considered significant. Analyses were performed with STATA V.15.

\section{RESULTS}

At enrolment, the age of the participants were: $38 \pm 10$ years. The age of immigration was: $26 \pm 10$ years. Years lived in the USA was: $12 \pm 9$ years. Independent of whether the participants were born in West, Central or East Africa, there were no differences in body size, fat distribution, glucose metabolism, liver function or demographic and social factors including alcohol intake (online supplementary appendix table 1). Therefore, the participants were combined into sex-specific groups independent of African region of origin.

Table 2 provides a comparison of the men and women. Degree of IR did not vary by sex. However, men had lower BMI, higher VAT and less SAT than women. Therefore, the WC that predicts IR was determined in a sex-specific manner.

\section{Glucose tolerance status}

With IR defined by HOMA-IR, the cohort was divided into four glucose tolerance categories: (1) NGT (2) NGT and IR (3) Abnl-GT and IR (4) Abnl-GT and not IR.

\section{Men}

The frequency of each glucose tolerance category was: $48 \%$ (120/250), 9\% (23/250), 15\%(38/250) and $28 \%$ (69/250), respectively.

\section{Women}

The frequency of each glucose tolerance category was: $58 \%$ (72/125), $14 \%$ (18/125), $12 \%(15 / 125)$ and $16 \%$ (20/125), respectively. 
Table 2 Population characteristics

\begin{tabular}{|c|c|c|c|c|}
\hline & $\begin{array}{l}\begin{array}{l}\text { Total } \\
(\mathrm{n}=375)\end{array} \\
\end{array}$ & $\begin{array}{l}\text { Men } \\
\text { Total }(n=250)\end{array}$ & $\begin{array}{l}\text { Women } \\
\text { Total } n=125\end{array}$ & P values* \\
\hline Age (years) & $38 \pm 10$ & $38 \pm 10$ & $37 \pm 10$ & 0.366 \\
\hline Body mass index $\left(\mathrm{kg} / \mathrm{m}^{2}\right)$ & $27.5 \pm 4.5$ & $27.2 \pm 3.9$ & $28.3 \pm 5.4$ & 0.020 \\
\hline Systolic blood pressure (BP) $(\mathrm{mm} \mathrm{Hg})$ & $120 \pm 14$ & $123 \pm 14$ & $115 \pm 13$ & $<0.001$ \\
\hline Diastolic BP (mm Hg) & $73 \pm 10$ & $74 \pm 10$ & $70 \pm 10$ & $<0.001$ \\
\hline Overweight (\%) & 70 & 71 & 67 & 0.426 \\
\hline WC1 $(\mathrm{cm}) \dagger$ & $90 \pm 11$ & $91 \pm 11$ & $89 \pm 13$ & 0.155 \\
\hline WC2 (cm)‡ & $89 \pm 11$ & $90 \pm 10$ & $86 \pm 12$ & 0.001 \\
\hline VAT $\left(\mathrm{cm}^{2}\right) \S$ & $99 \pm 70$ & $117 \pm 72$ & $63 \pm 48$ & $<0.001$ \\
\hline SAT $\left(\mathrm{cm}^{2}\right) \S$ & $153 \pm 96$ & $128 \pm 74$ & $203 \pm 114$ & $<0.001$ \\
\hline 0 hour glucose (mg/dL) & $92 \pm 12$ & $93 \pm 11$ & $89 \pm 12$ & 0.013 \\
\hline 2 hour glucose $(\mathrm{mg} / \mathrm{dL})$ & $132 \pm 39$ & $135 \pm 40$ & $126 \pm 39$ & 0.037 \\
\hline 0 hour insulin $(\mu \mathrm{U} / \mathrm{mL})$ & $6.9 \pm 5.2$ & $6.7 \pm 5.2$ & $7.3 \pm 5.1$ & 0.311 \\
\hline$\%$ Abnl-GTף & $38 \%$ & $43 \%$ & $28 \%$ & 0.005 \\
\hline HOMA-IR & $1.61 \pm 1.33$ & $1.59 \pm 1.37$ & $1.64 \pm 1.26$ & 0.731 \\
\hline Matsuda Index & $7.00 \pm 4.72$ & $7.08 \pm 4.88$ & $6.85 \pm 4.40$ & 0.659 \\
\hline Years in USA & $12 \pm 9$ & $11 \pm 9$ & $14 \pm 9$ & 0.005 \\
\hline Immigration age (years) & $27 \pm 10$ & $28 \pm 10$ & $24 \pm 11$ & $<0.001$ \\
\hline Married (\%) & 48 & 53 & 39 & 0.013 \\
\hline Health insurance (\%) & 69 & 66 & 76 & 0.040 \\
\hline College graduate (\%) & 71 & 71 & 71 & 0.936 \\
\hline
\end{tabular}

${ }^{*}$ Comparison is by unpaired t-test or $\chi^{2}$ as appropriate.

†Waist circumference (WC) is immediately above the iliac crest.

¥WC is midway between ribs and iliac crest, results available in 231 men and 115 women.

§Results for visceral adipose tissue (VAT) volume and subcutaneous adipose tissue (SAT) were available for 245 men and 123 women.

१Per cent abnormal glucose tolerant (Abnl-GT) (diabetes and prediabetes combined).

Figure 3 presents by sex and glucose tolerance category the distribution of: (A) BMI, (B) WC, (C) VAT, (D) SAT, (E) HOMA-IR and (F) insulinogenic index.

\section{Insulin-resistant categories}

The insulin-resistant categories include the men and women who were in group 2: NGT and IR, and group 3: Abnl-GT and IR.

Men

Twenty-four per cent $(61 / 250)$ of the men were insulin resistant (group 2 and group 3).

\section{Women}

Twenty-six per cent $(33 / 125)$ of the women were insulin resistant (group 2 and group 3).

\section{Abnl-GT categories}

The Abnl-GT categories include all the men and women in groups 3 and 4 .

\section{Men}

Forty-three percent $(107 / 250)$ of the men had Abnl-GT (group 3 and group 4). Of the 107 men with Abnl-GT,
99 had prediabetes and 8 had diabetes. These conditions were not previously known and diagnosed by the OGTT done at visit 2.

Women

Twenty-eight per cent $(35 / 125)$ of women had abnormal glucose tolerance (group 3 and group 4). Of the 35 women with Abnl-GT, 31 had prediabetes and 4 had diabetes. As with the men, the diagnosis of both prediabetes and diabetes was based on the OGTT done at visit 2.

\section{Abnl-GT without IR}

This category represents only group 4. As these individuals did not have IR, they would not be identified by WC.

Men

There are 69 men with Abnl-GT without IR. Insulinogenic index in groups 1 versus 4 were: $(1.4 \pm 1.0$ vs $0.9 \pm 0.5$, $\mathrm{p}=0.003$, respectively (Figure $3 \mathrm{~F}$ ). Hence, group 4 had significantly lower beta-cell secretion than group 1 .

Women

There are 20 women with Abnl-GT without IR. Insulinogenic ndex in groups 1 versus 4 were: $2.1 \pm 2.2$ vs $1.0 \pm 0.5$, 


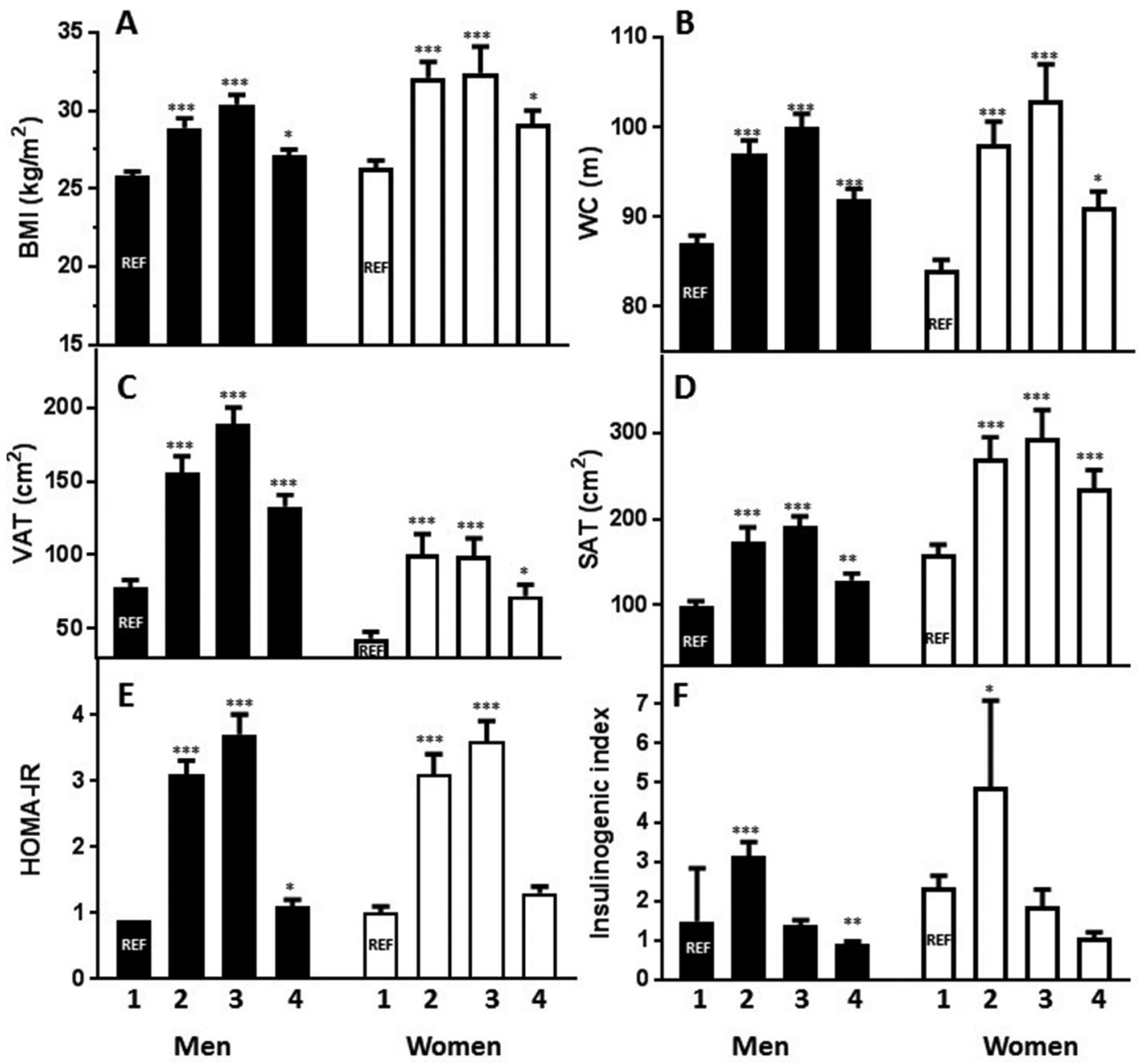

Figure 3 Metabolic characteristics by glucose tolerance group. Men: solid bars; women: open bars. Group 1: normal glucose tolerant (NGT) (reference group (REF)); group 2: NGT and insulin resistant (IR); group 3: abnormal glucose tolerant (Abnl-GT) and IR; group 4: Abnl-GT and no IR. (A) Body mass index (BMI); (B) waist circumference (WC); (C) visceral adipose tissue (VAT); (D) subcutaneous adipose tissue (SAT); (E) HOMA-IR; (F) insulinogenic index. Comparison with group 1 (NGT): *P $\leq 0.05$, ${ }^{* *} p \leq 0.01,{ }^{* * *} p \leq 0.001$.

$p=0.215$, respectively (figure $3 \mathrm{~F}$ ). While the insulinogenic index was lower in group 4 than group 1, the difference did not reach statistical significance.

All of the results described in this section were similar when IR categories were determined by the lowest quartile of Matsuda index (online supplementary appendix table 2) rather than the highest quartile of HOMA-IR (figure 3).

\section{Optimal WC to predict IR \\ Men}

Optimal WC1 (National Health and Nutrition Examination Survey (NHANES) method) for the prediction of IR was $91 \mathrm{~cm}$ for both HOMA-IR and Matsuda index (table 3, part A). Optimal WC2 (WHO method) for the prediction of IR was $92 \mathrm{~cm}$ for HOMA-IR and $91 \mathrm{~cm}$ for Matsuda index (table 3, part A). In the subset of men who had IR measured by the insulin sensitivity index, optimal WC for the prediction of IR by the insulin sensitivity index was $91 \mathrm{~cm}$.
Women

Optimal WC1 (NHANES method) for the prediction of IR was $96 \mathrm{~cm}$ for both HOMA-IR and Matsuda index (table 3, part B). Optimal WC2 (WHO method) for prediction of IR was $95 \mathrm{~cm}$ for HOMA-IR and Matsuda index (table 3, part B). The subset of women with IR measured by the insulin sensitivity index was too small for analyses.

Sex differences in the relationships between WC, VAT and SAT VAT was higher in men than women $(117 \pm 72$ vs $63 \pm 48$ $\mathrm{cm}^{2}, \mathrm{p}<0.001$ ) (figure 3C), but SAT was higher in women than men $\left(203 \pm 114 \mathrm{vs} 127 \pm 74 \mathrm{~cm}^{2}, \mathrm{p}<0.001\right)$ (figure $3 \mathrm{D}$ ). With WC as the dependent variable and VAT as the independent variable (adjusted $\mathrm{R}^{2}=0.57$ ), there was a significant interaction between sex and VAT $(p<0.001)$, so for every unit increase in VAT, the increase in WC was 0.07 units higher in women than men (figure 4A). With SAT as the dependent variable and VAT as the independent variable (adjusted $\mathrm{R}^{2}=0.53$ ), there was a significant 


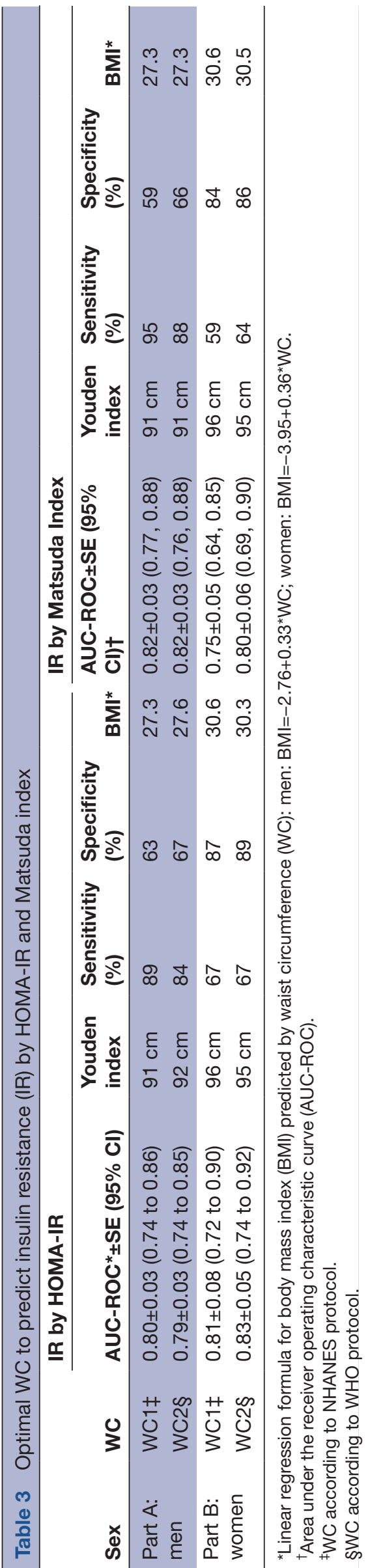

interaction between sex and VAT $(p<0.001)$, so for every unit increase in VAT, the increase in SAT was 0.94 units higher in women (figure 4B). To determine if length of stay in the USA influenced the relationship of VAT to either WC or SAT, the multiple regression was repeated adding years in the USA as an independent variable. In both cases, adjusted $R^{2}$ did not change and the $p$ value for years in the USA was $>0.50$.

\section{DISCUSSION}

This is the first examination of the relationship of VAT to IR and WC in a group of African-born black people living in America. The WC thresholds that optimally predicted IR in men and women were: $91 \mathrm{~cm}$ and $96 \mathrm{~cm}$, respectively. Importantly, studies conducted in South Africa, the Democratic Republic of Congo and Benin using less rigorous techniques also found that the WC that predicted IR was higher in women than men. ${ }^{13-20}$ The WC found to predict IR in these studies was in the range of 80-94 cm for men and 90-99 cm for women.

In short, our work with African-born adults living in America made it possible for us to validate results from studies conducted in Africa. Because we had the opportunity to measure VAT by CT scan, we were able to provide a metabolic basis for why the WC which predicted IR was higher in African women than men. IR is linked to VAT, and at every level of VAT, African women had more SAT than men; therefore, higher WC at the same level of VAT can be accounted for by sex differences in SAT. Interestingly, studies in Japan have also found that at similar levels of VAT, Japanese women have higher levels of SAT and a higher WC of risk than men. ${ }^{30}$ Hence, our finding that the WC that predicts IR is higher in women than men is not unique to Africans.

In the absence of either expert or consensus statements, the current practice of the International Diabetes Federation and AHA/NHLBI is to use WC thresholds determined in whites for sub-Saharan Africans. For women, IDF uses WC of $80 \mathrm{~cm}$ and AHA/NLBI use 88 $\mathrm{cm}$. For African women, these WC thresholds may be too low and will lead to over diagnosis of IR and the unnecessary utilisation of scarce resources. For men, the International Diabetes Federation uses WC of $94 \mathrm{~cm}$ and AHA/ NLBI use $102 \mathrm{~cm}$. For African men, the International Diabetes Federation threshold of $94 \mathrm{~cm}$ may be reasonable. In contrast, the AHA/NHLBI threshold of $102 \mathrm{~cm}$ is too high and will lead to under diagnosis of IR and lost opportunity for early intervention.

\section{Comparisons with data published in African-Americans}

Depending on gender, there are both similarities and differences between Africans and African-Americans. ${ }^{31}$ From studies we conducted earlier, we found that the WC that predicts IR is different in African and African-American men. ${ }^{26}$ However, among women of African descent, the WC that predicts IR does not vary by African descent population. $^{12}$ 

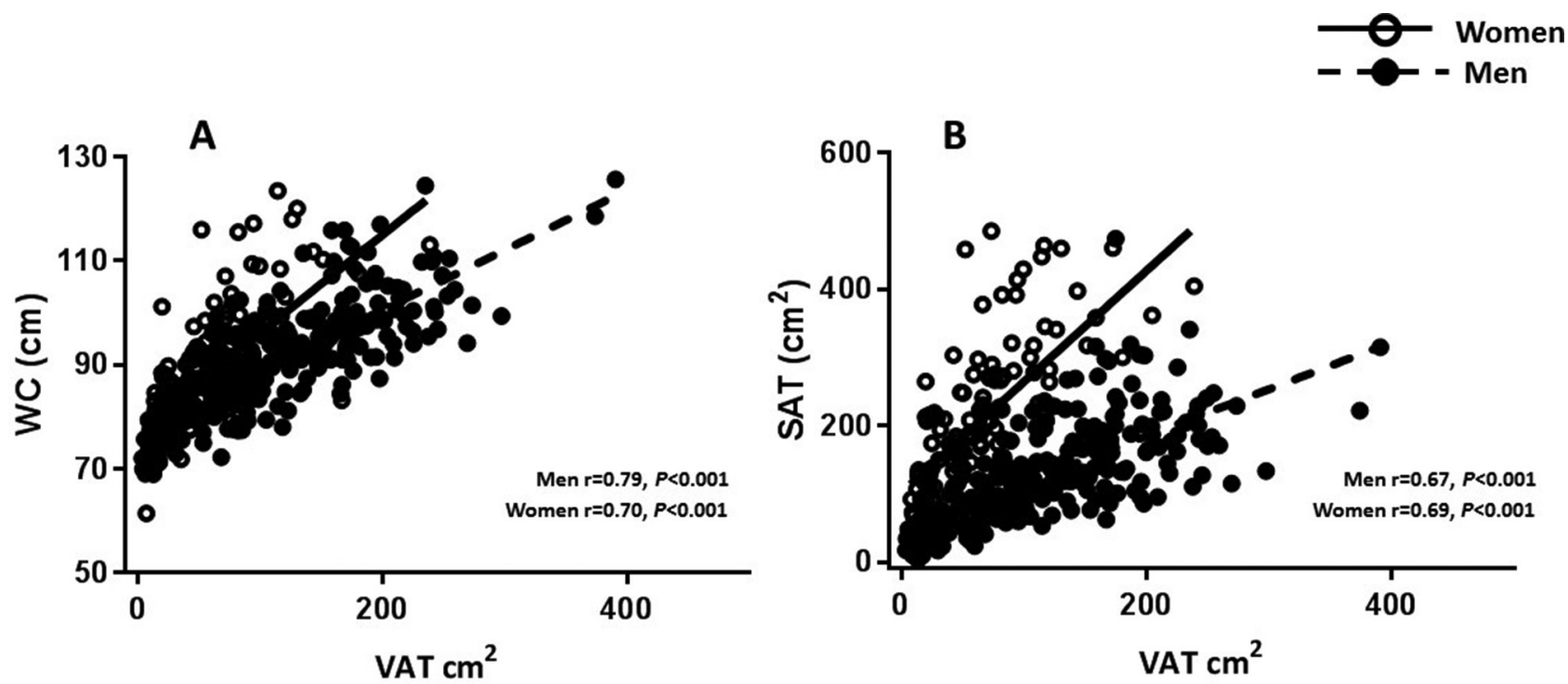

Figure 4 Correlations between central fat depots. Men: solid circles, dotted line; women: open circles, solid line. (A) Correlation of WC to VAT, interaction of sex and WC significant $p<0.001$, equation for men: WC $=77.62+0.12^{*} \mathrm{VAT}$; equation for women: WC $=77.43+0.19^{\star}$ VAT. (B) Correlation of SAT to VAT, interaction of sex and WC significant $p<0.001$, equation for men: $\mathrm{SAT}=47.56+0.69^{*} \mathrm{VAT}$; equation for women: SAT=101.44+1.63*VAT. VAT, visceral adipose tissue; WC, waist circumference.

We have previously conducted two investigations that enrolled both African immigrant and African-American men. ${ }^{26} 32$ In the first study, we examined cardiometabolic health and found that African immigrant men had a higher rate of Abnl-GT at a lower BMI and WC than African-American men. ${ }^{32}$ This study suggests that the WC of risk is lower in African immigrants than African-Americans, but this issue was not directly evaluated.

In the second study, the WC that predicted IR was specifically studied. ${ }^{26}$ With IR measured by $\mathrm{S}_{\mathrm{I}}$ and VAT ascertained by CT scan, we found that the WC that predicted IR was $92 \mathrm{~cm}$ in African immigrant men and $102 \mathrm{~cm}$ in African-American men. The WC that predicted IR in was lower in African immigrant men than African-American men because at every level of WC, African immigrant men had more VAT and less SAT than African-American men.

For women of African descent, the finding that WC of $96 \mathrm{~cm}$ predicts IR may be universal. In a pooled analysis of white South African, black South African, African immigrant and African-American women, all of whom had VAT measured by CT, there was a difference by race in the relationship of WC to VAT. ${ }^{12}$ White women had more VAT at every level of WC than the black women. However, among the black women, there was no difference between the three groups of black women in the relationship of WC to VAT. ${ }^{12}$ Furthermore, Katzmarzyk et al performed abdominal CT in the participants of the Pennington Center Longitudinal Study and reported that the WC that best predicted IR in African-American women was $96 \mathrm{~cm} .{ }^{33}$ Similarly in a study of African-Americans with IR determined by $\mathrm{S}_{\mathrm{I}}$, the WC that optimally predicted IR in African-American women was $98 \mathrm{~cm}^{34}$

\section{WC versus BMI}

Both cross-sectional and prospective studies of group of white people, Asians and Africans have found that as a predictor of risk for diabetes and heart disease, $\mathrm{WC}$ is equivalent or superior to BMI. ${ }^{35-37}$ Furthermore, WC is culturally acceptable and less costly to obtain than BMI. Measuring WC requires minimal training and only a non-stretch tape measure. In contrast, obtaining BMI requires two pieces of equipment both of which require calibration. This equipment is a scale placed on a level surface and a stadiometer mounted on a wall. In contrast to BMI, WC can be measured at virtually any indoor or outdoor event and most community gatherings. Furthermore, WC measurements are robust. In this study, WC was measured at two sites (ie, iliac crest and midway between the inferior rib and iliac crest), and the results, meaning the WC that predicted IR, varied by $1 \mathrm{~cm}$ or less.

\section{Abnl-GT in the absence of IR}

This investigation was designed to determine the relationship between WC and IR in Africans. However, in conducting this investigation, we discovered that $28 \%$ of men and $16 \%$ of women had Abnl-GT without IR. Presumably, the aetiology of Abnl-GT in this group is betacell failure. These individuals may be at higher risk for a type of diabetes known as ketosis-prone atypical diabetes. Other names for this type of diabetes include idiopathic type 1 diabetes, type $1 \mathrm{~B}$ diabetes, tropical diabetes and malnutrition-associated diabetes. ${ }^{38} 39$ The aetiology of ketosis-prone atypical diabetes is uncertain but theories include epigenetic changes due to early life undernutrition, exposure to infectious agents such as human herpes virus 8 , autoimmunity and primary genetic factors. ${ }^{38-41}$ 
Both the prevalence and natural history of asymptomatic individuals with Abnl-GT without IR are unknown. We were able to detect these individuals because we performed multisampled OGTT, which allowed us to measure both IR and estimate beta-cell secretion. We speculate that the individuals in group 4 may be experiencing the asymptomatic prodrome of ketosis-prone atypical diabetes. Going forward, it is important to design studies to prospectively determine the natural history of Africans with Abnl-GT and no IR.

\section{Strengths and weaknesses}

The participation of a group of African-born black people from countries spanning West, Central and East Africa is a strength of this study. Yet, we recognise that there was virtually no participation of Africans from South African countries. However, our results are consistent with publications from South Africa. ${ }^{14} 16{ }^{18-20}$ Another strength is that to evaluate IR, we used both HOMA-IR and Matsuda index and in a subset of the men we had access to $S_{I}$ data. Plus we measured WC at two levels. In addition, we had opportunity to perform CT scans in African-born men and women and directly visualise VAT and SAT. Data from the CT studes provided critical insight into why the WC of risk is higher in African women than men.

The investigation has four weaknesses. Although this is the largest most intensive study of WC thresholds in an African population, the sample size is 375 . Nonetheless, this sample size is large enough to change the dialogue, initiate debate and ultimately contribute to the formation of African-specific guidelines for WC. The second challenge is the cross-sectional design. A cross-sectional study can be used to identify the WC associated with IR in Africans but not the clinical consequences. Third, this investigation was designed to determine the association between IR and WC and not the cause of IR. Fourth, this study enrolled a group of African-born black people living in America rather than Africa. However, our study results were similar to studies conducted in Africa. Furthermore, multiple regression analyses revealed that the variable 'years in the United States' had no significant effect in either men or women on the relationship between IR, WC and VAT.

\section{CONCLUSIONS}

For preventing IR-related disease in Africans, the best way forward is to use African-centred thresholds for biomarkers such as WC. Working with a group of African-born black people living in America, we found that the optimal WC for the prediction of IR in Africans was $91 \mathrm{~cm}$ in men and $96 \mathrm{~cm}$ in women. Overall, our results validate earlier studies that were conducted in Africa and depended on less rigorous technology (table 1).${ }^{13-20}$ Now may be the time to call for a systematic review of the literature and the development of a consensus statement, so current practice on the use WC to predict IR in Africans can be updated.

\section{Author affiliations}

${ }^{1}$ Section on Ethnicity and Health, Diabetes, Endocrinology, and Obesity Branch, National Institute of Diabetes, Digestive and Kidney Diseases, Bethesda, Maryland, USA

${ }^{2}$ National Institute of Minority Health and Health Disparities, Bethesda, Maryland, USA

${ }^{3}$ Clinical Center, National Institutes of Health, Bethesda, Maryland, USA

${ }^{4}$ University of Colorado Anschutz Medical Campus, Aurora, Colorado, USA

Contributors JDK, RLB, RHE and AES did the literature search. ABC and AES designed the study. JDK, RLB, SMB, LSM, CWD, STC and AES contributed to enrolment. JDK, RLB, SMB, ABC, LSM, CWD, STC and AES collected the data. JDK, RLB, SMB, ABC, LSM, CWD, STC and AES analysed the data. JDK and AES made the figures. JDK, RLB and AES made the tables. JDK, RLB, SMB, ABC, LSM, CWD, STC, RHE and AES wrote the manuscript and JDK, RLB, SMB, ABC, LSM, CWD, STC RHE and AES provided critical rewrites of the manuscript.

Funding The study was funded by the intramural research program of two NIH institutes: NIDDK, NIMHD and the NIH Clinical Center. JDK and AES are supported by the intramural programs of both NIDDK and NIMHD. RLB, SMB, CWB, LSM and STC are supported by the intramural programme of NIDDK. ABC is supported by the NIH Clinical Center.

\section{Competing interests None declared.}

Patient consent Not required.

Ethics approval NIDDK Institutional Review Board.

Provenance and peer review Not commissioned; externally peer reviewed.

Data sharing statement We do not refer to any unpublished data.

Open access This is an open access article distributed in accordance with the Creative Commons Attribution Non Commercial (CC BY-NC 4.0) license, which permits others to distribute, remix, adapt, build upon this work non-commercially, and license their derivative works on different terms, provided the original work is properly cited, appropriate credit is given, any changes made indicated, and the use is non-commercial. See: http://creativecommons.org/licenses/by-nc/4.0/

\section{REFERENCES}

1. IDF, 2017. IDF Diabetes Atlas - 8th Edition. http://www.diabetesatlas. org

2. Mensah GA, Roth GA, Sampson UK, et al. Mortality from cardiovascular diseases in sub-Saharan Africa, 1990-2013: a systematic analysis of data from the Global Burden of Disease Study 2013. Cardiovasc J Afr 2015;26(2 Suppl 1):S6-10.

3. Alberti KG, Eckel RH, Grundy SM, et al. Harmonizing the metabolic syndrome: A joint interim statement of the International Diabetes Federation Task Force on Epidemiology and Prevention; National Heart, Lung, and Blood Institute; American Heart Association; World Heart Federation; International Atherosclerosis Society; and International Association for the Study of Obesity. Circulation 2009;120:1640-5.

4. Eckel RH, Alberti KG, Grundy SM, et al. The metabolic syndrome. Lancet 2010;375:181-3.

5. Eckel RH, Grundy SM, Zimmet PZ. The metabolic syndrome. Lancet 2005;365:1415-28.

6. WHO. Waist Circumference and Waist-Hip Ratio, Report of a WHO Expert Consultation (WHO Technical Report Series 894). 2008.

7. Banerji MA, Chaiken RL, Gordon D, et al. Does intra-abdominal adipose tissue in black men determine whether NIDDM is insulinresistant or insulin-sensitive? Diabetes 1995;44:141-6.

8. Boyko EJ, Fujimoto WY, Leonetti DL, et al. Visceral adiposity and risk of type 2 diabetes: a prospective study among Japanese Americans. Diabetes Care 2000;23:465-71.

9. Després JP. Body fat distribution and risk of cardiovascular disease: an update. Circulation 2012;126:1301-13.

10. Fujimoto WY, Bergstrom RW, Boyko EJ, et al. Visceral adiposity and incident coronary heart disease in Japanese-American men. The 10year follow-up results of the Seattle Japanese-American Community Diabetes Study. Diabetes Care 1999;22:1808-12.

11. Lebovitz HE, Banerji MA. Point: visceral adiposity is causally related to insulin resistance. Diabetes Care 2005;28:2322-5

12. Sumner AE, Micklesfield LK, Ricks M, et al. Waist circumference, BMI, and visceral adipose tissue in white women and women of African descent. Obesity 2011;19:671-4. 
13. Agueh VD, Sossa C, Ouendo DM-E. Determination of the optimal waist circumference cut-off points in benin adults. Open J Epidemiol 2015;0504:217-28.

14. Crowther NJ, Norris SA. The current waist circumference cut point used for the diagnosis of metabolic syndrome in sub-Saharan African women is not appropriate. PLoS One 2012;7:e48883

15. El Mabchour A, Delisle H, Vilgrain C, et al. Specific cut-off points for waist circumference and waist-to-height ratio as predictors of cardiometabolic risk in Black subjects: a cross-sectional study in Benin and Haiti. Diabetes Metab Syndr Obes 2015;8:513-23.

16. Hoebel S, Malan L, Botha J, et al. Optimizing waist circumference cut-points for the metabolic syndrome in a South African cohort at 3-year follow-up: the SABPA prospective cohort. Endocrine 2014;47:959-61.

17. Katchunga PB, Hermans M, Bamuleke BA, et al. Relationship between waist circumference, visceral fat and metabolic syndrome in a Congolese community: further research is still to be undertaken Pan Afr Med J 2013;14:20.

18. Motala AA, Esterhuizen T, Pirie FJ, et al. The prevalence of metabolic syndrome and determination of the optimal waist circumference cutoff points in a rural South african community. Diabetes Care 2011;34:1032-7.

19. Peer N, Steyn K, Levitt N. Differential obesity indices identify the metabolic syndrome in Black men and women in Cape Town: the CRIBSA study. J Public Health 2016;38:175-82.

20. Prinsloo J, Malan L, de Ridder JH, et al. Determining the waist circumference cut off which best predicts the metabolic syndrome components in urban Africans: the SABPA study. Exp Clin Endocrinol Diabetes 2011:119:599-603.

21. Sumner AE, Duong MT, Bingham BA. Glycated albumin identifies prediabetes not detected by hemoglobin a1c: The africans in america study. Clin Chem 2016;62:1524-32.

22. Sumner AE, Thoreson CK, O'Connor MY, et al. Detection of abnormal glucose tolerance in Africans is improved by combining A1C with fasting glucose: the Africans in America Study. Diabetes Care 2015;38:213-9.

23. Utumatwishima JN, Baker RL, Bingham BA, et al. stress measured by allostatic load score varies by reason for immigration: the africans in america study. J Racial Ethn Health Disparities 2018;5:279-86.

24. Yu SS, Ramsey NL, Castillo DC, et al. Triglyceride-based screening tests fail to recognize cardiometabolic disease in African immigrant and African-American men. Metab Syndr Relat Disord 2013;11:15-20.

25. American Diabetes Association. 2. Classification and Diagnosis of Diabetes: Standards of Medical Care in Diabetes-2018. Diabetes Care 2018;41(Suppl 1):S13-27.

26. O'Connor MY, Thoreson CK, Ricks M, et al. Worse cardiometabolic health in African immigrant men than African American men: reconsideration of the healthy immigrant effect. Metab Syndr Relat Disord 2014:12:347-53.

27. Boston RC, Stefanovski D, Moate PJ, et al. MINMOD Millennium: a computer program to calculate glucose effectiveness and insulin sensitivity from the frequently sampled intravenous glucose tolerance test. Diabetes Technol Ther 2003;5:1003-15.

28. Patry-Parisien J, Shields M, Bryan S. Comparison of waist circumference using the World Health Organization and National Institutes of Health protocols. Health Rep 2012;23:53-60.

29. Harris PA, Taylor R, Thielke R, et al. Research electronic data capture (REDCap)-a metadata-driven methodology and workflow process for providing translational research informatics support. J Biomed Inform 2009;42:377-81.

30. New criteria for 'obesity disease' in Japan. Circulation Journal: official Journal of the Japanese Circulation Society 2002;66:987-92.

31. Utumatwishima JN, Chung ST, Bentley AR, et al. Reversing the tide diagnosis and prevention of T2DM in populations of African descent. Nat Rev Endocrinol 2018;14:45-56.

32. Ukegbu UJ, Castillo DC, Knight MG, et al. Metabolic syndrome does not detect metabolic risk in African men living in the U.S. Diabetes Care 2011;34:2297-9.

33. Katzmarzyk PT, Heymsfield SB, Bouchard C. Clinical utility of visceral adipose tissue for the identification of cardiometabolic risk in white and African American adults. Am J Clin Nutr 2013;97:480-6.

34. Sumner $A E$, Sen $S$, Ricks $M$, et al. Determining the waist circumference in african americans which best predicts insulin resistance. Obesity 2008;16:841-6.

35. Hardy DS, Stallings DT, Garvin JT, et al. Anthropometric discriminators of type 2 diabetes among White and Black American adults. J Diabetes 2017;9:296-307.

36. Mbanya VN, Kengne AP, Mbanya JC, et al. Body mass index, waist circumference, hip circumference, waist-hip-ratio and waist-heightratio: which is the better discriminator of prevalent screen-detected diabetes in a cameroonian population? Diabetes Res Clin Pract 2015;108:23-30.

37. Vazquez G, Duval S, Jacobs DR, et al. Comparison of body mass index, waist circumference, and waist/hip ratio in predicting incident diabetes: a meta-analysis. Epidemiol Rev 2007;29:115-28.

38. Lontchi-Yimagou E, Nguewa JL, Assah F, et al. Ketosis-prone atypical diabetes in cameroonian people with hyperglycaemic crisis: frequency, clinical and metabolic phenotypes. Diabet Med 2017:34:426-31.

39. Sobngwi E, Choukem SP, Agbalika F, et al. Ketosis-prone type 2 diabetes mellitus and human herpesvirus 8 infection in sub-saharan africans. JAMA 2008;299:2770-6.

40. Balasubramanyam A, Nalini R, Hampe CS, et al. Syndromes of ketosis-prone diabetes mellitus. Endocr Rev 2008;29:292-302.

41. Gill GV, Mbanya JC, Ramaiya KL, et al. A Sub-Saharan African perspective of diabetes. Diabetologia 2009;52:8-16. 